\title{
Financial Facilities And Sustainable Child Labour Programmes In Ghana
}

\author{
Samuel Kwofie \\ Kwame Nkrumah University of Science and Technology; \\ Koforidua Technical University, Ghana \\ Kweku Dwomor Kessey \\ Department of Planning, \\ Kwame Nkrumah University of Science and Technology. \\ Kumasi. Ghana \\ Romanus Dinye \\ Centre for Settlement Studies. \\ Kwame Nkrumah University of Science and Technology. \\ Kumasi. Ghana
}

\begin{abstract}
Government of Ghana and other stakeholders have been putting up a lot of interventions to handle child labour related issues. Skill Development Training(s) have been provided the parents and guardians of these children. This study seeks to link up with the necessary financial institutions so that they could assist these vulnerable people to make the withdrawal process sustainable. This exercise used largely qualitative research method and marginally quantitative type. It was established that , there exist financial and micro- credit schemes within the country; poor arrangements of funding services to benefit the empowered family, high credit risk among empowered family. It was recommended that the micro financial institutions should define pro- poor products; implementing agencies should factor their training to include better skills development programmes that could help the target groups by making them attractive. It was concluded that to make the withdrawal process more formidable, there is the need to liaise with the funding agencies that can support these people.
\end{abstract}

KEYWORDS: sustainable; empowered; withdrawal; funding services; stakeholders

\section{OVERVIEW AND CONCEPTUALISATION}

Governments and their stakeholders globally have various projects and programmes that aimed at withdrawing child labour victims of which Ghana is not excluded. Some of these projects include,' Let's join hands to fight child labour: SCREAM module on HIV, AIDS and child labour (Uganda, 2015); 'Teachers' trade unions mainstream the topic of child labour in education curricula for children and teachers (Tajikistan, 2015); Eliminating hazardous child labour and occupational safety, health and environmental risks: A manual for agents of change in cocoa communities in Ghana. (2015).

The engagement of children in various socio-economic activities is widespread and the practice has existed for several decades now. "One in every six children aged 5 to 17 worldwide is exploited by child labour in its different forms, according to estimates made by the ILO in 2002 and repeated in 2010 and 2014. In addition, Ghana Living Standard Survey, round 6, demonstrated that 21.8 percent of children are engaged in child labour activities. As abhorrent 
as the practice is, the international community has tended to give the issue a serious attention culminating in the collective action to stem the practice. The ILO conventions, national legislations and regulations of workers and employers organisations have strongly kicked against the engagement of children in labour. Several reasons have been assigned for use of children in labour of which poverty remains one of the key factors. Child labour may result from the desire of children themselves to work for personal gains, but the most significant driving force is to provide support for sustenance of families. The impact is that children risk their education, health, decent childhood and responsible adulthood.

Ghana recognises the problem of child labour given the number of children engaged in the practice. The immediate response is that the Government of Ghana is cooperating with the ILO for the implementation of national programme to combat child labour practices. Consequently, in the year 2000, Ghana ratified the ILO convention 182 on the Worst Forms of Child Labour (WFCL) and further signed a Memorandum of Understanding (MoU) with the ILO for technical cooperation on actions against child labour. Key technical cooperation projects which resulted from these initiatives include ILO-IPEC Ghana Country Programme (2000-2003), Combating trafficking in children in West and Central Africa (2001-2006), The West Africa Cocoa and Commercial Agriculture Programme to Combat Hazardous and Exploitative Child Labour (2002-2006), Capacity Building for the elimination of child labour (2002-2006) and Skills training strategies to combat WFCL in the urban informal sector in Anglophone sub-Saharan Africa (A regional skills training project, 2004-2007). All these interventions have one key thing in common - the withdrawal of children from WFCL, rehabilitation and education/training, but they also largely go beyond this core area to include provision of empowerment interventions for parents and guardians of the children with the view of improving the family support systems to make the child labour withdrawal process formidable Further to the child labour elimination processes, there have been several efforts by involving other stakeholders to prevent and withdraw children from exploitative work, rehabilitate and place them in formal education and apprenticeship training. There are other efforts which involve provision of skills and management training towards economic empowerment of parents and guardians.

\section{Statement of the Problem}

The child labour elimination process is an investment whose economic returns accrue overtime. The investment made in children with respect to formal education yield economic gains in several decades. On the other hand, the benefits of informal training accrue is relatively a shorter period. Yet for economic skills and management training, which are largely short-time investments, the economic returns is reflected by the positive impact that other direct investment in fiscal terms could provide.

The Government of Ghana with the help of other stakeholders have been able to provide the necessary skills and training as part of empowering families to support the investment in the child labour elimination process. The general expectations is that beneficiaries have themselves committed time and energy and backed by injection of capital from a second source and have moved beyond their current level of extreme poverty to providing the needed support to their families to sustain formal and informal training which the withdrawn children are being offered through interventions.

Empirical evidence, on the contrary points to the fact that nearly all target groups have not been able to access financial capital in the least substantial levels to be able to start any economic activities. It was stated by the country Director of ILO during the world child labour day that, those withdrawn are always found at the same place when tracer surveys were 
conducted. The obvious reasons for this state is that majority of the target groups are poor, without resources and with little livelihood opportunities to make claim of their rights and entitlements. Their circumstances seem unattractive to financial service providers.

Ghana has a very vibrant financial sector consisting of the following formal, semi-formal and informal institutions: Bank of Ghana, over 30 commercial banks (BoG, 2014), Micro-Finance Associations (MFAs) with a numerical strength of 409 according to Bank of Ghana (2014), about 120 Rural and Community Banks (RCBs), Savings and Loans (S\&L) companies, credit granting NGOs and Credit Unions, Susu collectors and traditional money-lenders. There are over 409 regulated MFIs that serve over 500,000 clients in Ghana; yet large numbers of poor and vulnerable families, even though empowered with technical skills, are unable to access funding services to improve their livelihoods.

The study took into consideration the vulnerable people and focused on the withdrawn victims and groups that have been empowered through skills training and thus requires capital to produce beyond subsistence level. But at the same time, they are constrained by the systems that govern credit provision by funding agencies in Ghana.

In the light of the important role that credit plays in the development of micro-enterprises and the problems vulnerable and low income families/groups face in accessing credits, it is important to have an in-depth study into their operational arrangements that meet the broad funding needs of this group. This will provide sound basis for the design and implementation of criteria and mechanisms that would enhance the growth and development of the economic life of the target groups.

The study therefore drew on the credit-line operations of funding agencies in Ghana and related it to the specific capital requirements of empowered but vulnerable and low income families (i.e. target groups) in a process of uplifting target groups chances of accessing credits to improve their livelihoods.

\section{Objectives of the Study}

The goal of the study is to improve access to and utilisation of funding services for victims and families who have benefitted from child labour elimination interventions in Ghana in order to ensure sustainability of their withdrawals.

Specific objectives of the study include:

a. To identify funding schemes (especially micro-finance institutions) relevant to extend services to benefit target groups at the local level;

b. To provide detailed information on the target groups including their capability to benefit from the available services of funding agencies;

c. To develop criteria to enable empowered target families and groups' access credits and other funding services;

\section{Study Design and Scope of the Work}

There is generally inadequate data on the number of target groups who have received similar interventions but who are unable to attract the confidence of financial services providers countrywide. For the GoG/ILO in particular, the available data relates to number of parents and guardians reached by IAs who solely concerned themselves with empowerment interventions or both empowerment and direct child labour withdrawal. It is therefore critical that the study based on both theoretical and empirical investigations. Theoretical dimensions of investigations focused on the efforts of various stakeholder institutions and interventions to 
address the problem of inadequate access to funding and whilst empirical investigations largely related to the issues as they pertain to the GoG interventions within the purview of the funding arrangements and access.

\section{Processes of Handling Child labour Issues in Ghana}

Government of Ghana together with other stakeholders have made a lot of attempts at handling Child labour related issues. Human Right Watch, (2015) has been able to identify various areas where children were found working in the Mining areas of Ghana. They went further to provide information about the negative impacts that these mining activities renders to these children artisans. Some of these impacts mentioned included Health hazards, education, prostitutions, accidents and mention but a few. Sackett (2007) in her work 'Forced Child Labour and Cocoa Production in West Africa', discovered that there were over 10,000 children found in the area of cocoa production in Ghana and suggested to the policy makers to take a pragmatic solution to curb these menace. Attempts were made by the Government of Ghana and ILO to withdraw these children. (M\&E, NDPC, 2014). International Programme on Elimination of Child Labour (IPEC) in Combating child labour in Cocoa Growing areas also came out with the idea of appealing to the various employers to desist from employing children to work for them. This initiated 'International Cocoa Initiative: Working towards responsible labour standards for Cocoa Growing'.

Government of Ghana and ILO have signed a Memorandum of Understanding (MoU) for technical cooperation on actions against child labour. Key technical cooperation projects which resulted from these initiatives include ILO-IPEC Ghana Country Programme (2000-2003), Combating trafficking in children in West and Central Africa (2001-2006), The West Africa Cocoa and Commercial Agriculture Programme to Combat Hazardous and Exploitative Child Labour (2002-2006), Capacity Building for the elimination of child labour (2002-2006) and Skills training strategies to combat WFCL in the urban informal sector in Anglophone subSaharan Africa (A regional skills training project, 2004-2007). All these interventions had one key thing in common - the withdrawal of children from WFCL, rehabilitation and education/training, but they have also largely gone beyond this core area to include provision of empowerment interventions for parents and guardians of the children with the view of improving the family support systems to make the child labour withdrawal process formidable.

\section{Process of Funding Economic Activities of child labour Victims in Ghana}

The need for financial services that allow people to take advantage of opportunities to undertake economic activities and to move themselves from low income household status have been a key concern of successive governments and this pre-dates independence. The arrangements have basically been a practice where people save and take money for economic activities (mainly farming and small businesses/micro-enterprises) within the spirit of selfhelp. The major sources had been family relations, close associates, credit unions, self-help groups, savings collectors, cooperative societies and Rotating Savings and Credit Associations (ROSCAs). (NDPC, APR.2012 and Mohammed et al 2013).

It is known that though these informal financial institutions and arrangements have limited outreach due primarily to paucity of loanable funds, the arrangements have the propensity to attract the poorest, reaching far down into the populations with characteristics as the target groups. On the contrary, there have been little conscious efforts to organise a system that accommodates the special constraints that confronts majority of the individuals and groups that fall outside the services offered by the conventional formal financial institutions in Ghana. The challenges of the funding system is further compounded by the fact that the very poorest of society have limited capacity to be attractive because beyond their state of poverty, they are 
mostly unskilled, without any meaningful livelihood opportunities and might certainly not be able to pay back credits advanced to them. The populations within conflicts and post conflicts areas equally stand the risk of being attacked, a situation which does not offer opportunities to rebuild themselves. (Lane, 2014).

\section{METHODOLOGY}

The assignment relied heavily on current relevant secondary and primary data. Recognising through literature that numerical data were not available and few ones scattered, it requires the researcher to conduct initial baseline and planning studies to ensure that acceptable scope and quality of planning information and baseline data were assembled. Based on the initial discussions and consultations between the researcher and other stakeholders, the researcher designed information gathering tools.

Generally, the instruments focused on basic qualitative and quantitative research methods. Qualitative methods were applied to collect data that could not have been quantified such as opinions, perceptions, ideas and to explain why and how of quantitative data. A key approach for obtaining qualitative data was the use of Participatory Research instrument such as questionnaire administration, key informant interviews, group interviews, focus group discussions and direct observations. Generally participatory exercises used these tools to get information, visualize, analyse and interpret data.

The assessments of the extent to which victims of child labour and their parents/guardians become attractive and are reached by funding services require quantitative and qualitative investigations. Quantitative because if funding services exist and victims have been met, it was important to assess the numerical data in terms of geographical coverage and people reached with services. On the other hand qualitative investigations was necessary because it was crucial to assess the strengths of the credit markets, attractiveness of the target groups and the impact of funding provision of productive capacity of target groups. The specific methodological parameters are outlined.

\section{Research Process}

The study employs two levels of enquiry which is necessary in responding to the two prepositions - first an enquiry about the funding arrangements and operational procedures of funding agencies (including banking and non-banking financial agencies); and the second the existing capacity and constraints of the target groups to access funding services. The study also employed a clear set of logical sequence to delineate policy, approaches and preferences; seek explanations and drew conclusions within the defined scope of work under the ultimate objective of the study.

\section{Data Gathering Procedure}

Data was gathered from two main sources namely the National, District levels on one hand and by sectors on the other. This also involves secondary and primary source information. From the secondary sources, published and unpublished sources information were gathered. The primary source information involved consultations and administration of structured and semistructured information gathering instruments.

\section{Data Sources}

The secondary data for the research were mainly gathered from documents of bank and nonbank financial institutions, micro-credits agencies, Government published and ministerial reports, related project documents. These were complemented with empirical evidence-based 
information gathered through formal and informal interviews and extensive consultations with institutions, target groups and other key sector stakeholders.

\section{Analytical Process}

The study investigated marginally into the quantitative basis to determine the coverage of micro-financing within the context of the broader goal of the research. The essence is to establish the extent of services provided to target groups served with financial products. Much of the analysis dwelt on exploratory techniques. In this context, the use of extensive qualitative analysis was due to the need to place greater emphasis on the possibilities of promoting flexible funding arrangements that responded to the needs of the poor, vulnerable and excluded members of the society who have been empowered through skills training.

The study uses the loose forms of "transactional" and "decision-making" approaches in arriving at conclusions and proposals for action. From both the perspective of the funding agencies and target groups, the "transactional approach" adopts an actor-oriented or interactionist perspective in which the interpersonal relationships adopted by the funding agencies on one hand and empowered families/group on the other were identified and analysed. The essence of this methodology is to understand more fully the various ways in which each of the two entities (funding agencies or target groups) involvement in types of economic and social networks influence their decision-making and performance in business. The "decision-making" approach focuses on actor rationality. For either of the two entities, their respective roles require a flow of decision-making about resource mobilisation, profit-making, maximizing performance and establishing networks to take advantage of the existing opportunities. Thus, the Transactional and Decision-Making Approaches (TRADEMAP) offered an opportunity for explaining the often derided economic irrationality of institutional support to micro-enterprise development.

\section{Characteristics of Target Groups}

\section{RESULTS AND DISCUSSION}

The study investigated the characteristics of the target groups as a prelude to the assessment of the extent of attractiveness of the group to funding agencies. Field investigations revealed the following characteristics of target groups:

\section{Poor and vulnerable segment of the community (Income Poverty)}

The empowered families are largely parents and guardians whose children were engaged in child labour. The economic livelihoods of the target groups do not yield much income that could sustain the family even when the provision of basic needs is just to be met. Over 80 percent of the families engaged in focus group discussions indicated that income earned by children either directly or indirectly supplement family income. To the extent that they barely meet the social needs of the children clearly demonstrates that they are poor; a significant number live in the lower percentile of the income poverty line.

The situation is worse for parents in the three Northern Regions, Central and Volta regions. The implications are that the national regional poverty indices impacts on the situation of families. Given the principle upon which MF thrives, the target groups will continue to face extreme difficulty in accessing funding for economic activity without effective monitoring. It further implies that provision of financial services for these categories of empowered families must be backed by meaningful non-financial services. 


\section{Insecure livelihoods options}

The economic livelihoods of the target groups are so fused to the extent that it is difficult to distinguish between major and minor livelihoods. All livelihoods of households go to complement each other in sustaining the family. In most of the districts, empowered target groups are engaged in farming, fishing and trading whilst a significantly low number engage in other forms of economic activities including artisanal activities, carrying of ore at "galamsey" sites, breaking of stones at quarry sites etc. In some minimal cases, parents/guardians have no livelihoods at all and depend on proceeds from the children in labour.

Box 1: Concerns of a potential beneficiary
"This is all what I do to support my family. Brother, I have a
small cassava and pepper farm of about 1 acre so I go there
everyday except Sundays. In the evening the children help me
to sell 'kalawale' and we close at 10.30 pm. On taboo days I go
with the children to the market to carry wares for people who
come to trade. Yes, I have received the training but I cannot
start anything on my own. No money, not even that to feed
these four children"
--quote from an empowered parent in the Twifo-Praso

\section{Lack of Safety Nets}

All empowered families lack safety nets, whether the social security provided by government agency (SSNIT) or the traditional forms of social security. Thus the future cannot be guaranteed because children engaged in child labour lack education, have no skills and have limited knowledge to be able to provide safety net for parents. Incomes are low and trickles in daily, all culminating in insecure livelihoods. The implications are that safety nets, irrespective of where the assessment is taken from, do not go beyond a day; and if anything at will not exceed one week.

\section{Largely illiterate to the core or very minimal education}

Education enables everyone to learn about the requirements for services yet to be accessed and this is quite crucial. The empowered families are either illiterate or have very elementary education which restricts their capacity to learn, plan and initiate meaningful economic activities and to be able to assert themselves.

\section{Low savings culture}

Savings is a vital part of any microfinance intervention as it is important both for the lender and the clients. The lender can use savings mobilised to build up the revolving fund and also as de facto collateral for loans. Given their limited returns from any endeavour, coupled with high risk and poor health implications, savings (both voluntary and compulsory) is very limited or virtually lacking. In about the 5 percent who indicated that they do savings, it is small and trickles in unevenly. The tendency is that provision of microfinance to the large segment is almost impossible.

\section{Suffer exclusion at all levels}

The very characteristics of the empowered families, poverty being the most obvious impact, erases the individual's (and indeed the families) ability to make use of his or her right and to participate in decisions that affect them. Field visits show clearly that empowered families are unable to contribute meaningful to communal decisions. Where they make efforts to 
participate, they are marginalised and recognised at the periphery. Thus, the economic, social and political lives of empowered families are not strong enough like the situation is for their counterparts within the same society who are on the other side of the continuum. The other dimension of their plight is that they live in fear and ignorance and are thus unable to assert themselves to take advantage of situations that potentially can uplift them from poverty.

Box 2: Definition of Social Exclusions
"Social exclusion refers to limited/inequitable opportunities
and capabilities to participate in decision making, gain access
to meaningful livelihood opportunities and social services due
to discriminatory institutional practices in the political,
economic, social spheres based on gender, ethnicity,
geographical location, age, income status, health status,
educational attainment and disability"
Source: GHDR (200) Towards and Inclusive Society

\section{Low investment Capacity}

If savings generates investments, then the obvious implications of the low savings among empowered families is low capacity to invest in physical assets and in human resources including educating their children in formal and informal education. In deed the underlying factor of child labour is poverty, complemented by ignorance and obnoxious traditions.

\section{Low access to community's economic resources}

The factors that exclude empowered families also results in their inability to take advantage of available community resources and are thus, compelled to live within the lower subsistence level of the economy.

\section{Capacity Assessment of Target Groups to Access Funding Services Current Fund Sources of empowered families}

The main types of sources of credit for the empowered families are the formal and informal sources. Formal sources include banks and some other special credit and micro-finance programmes offered by non-bank financial institutions and some NGOs. They apply formal banking regulations that go with credit offers and involve formal assessment of business/enterprise ventures, provision of guarantee with collateral and often limited negotiations for schedule and mode of payment.

The informal sources include support from money lenders, relatives, buyers and informal credit unions called in local parlance as "Susu". These sources do not normally have defined lending interest rates. The basic criterion is "trust". However, for money lenders, there is often the demand for a commensurate collateral security which may be in the form of landed property, jewellery or industrial crop farm. The lending rate purging between 63 to 66 per cent.

The other source which involves provision of institutional and technical support, occasionally include subsidies and grants come from poverty alleviation projects, civil society organisations and government interventions.

\section{Constraints confronting Target Groups to Access Funding}

Assessing the constraints of target group's access to funding services across all the districts visited, the following key constraints were noted as presented in figure 2 below 
Fig 2: Rural-Urban Split of impact of constraints to accessing funding

Differential impact of

Constraints to access to

Funding Services

\section{Rural Context}

Severe impact of the constraining factors on target groups:

- Acute limitation of knowledge of funding facilities

- Near unavailability of sources of institutionalised funding

- Fear of taking large amounts of credits/loans

- Difficulty to reach funding sources
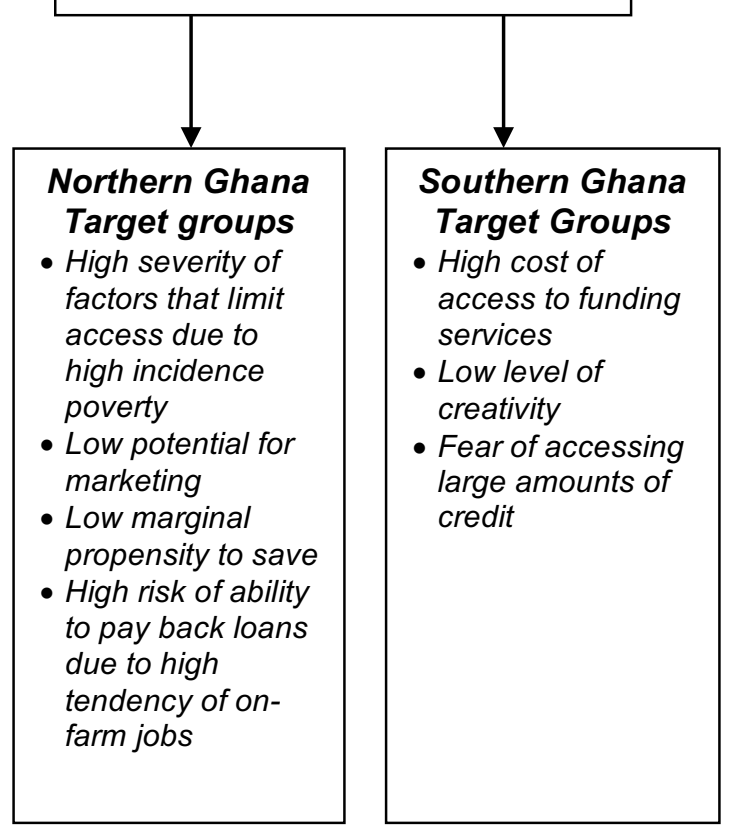

\section{Urban Context}

Differential impact of constraining factors on target groups

- Peri-urban target groups are constrain by cost associated with access of funding services

- Urban target groups are confronted with problems of group formation due to low social networks

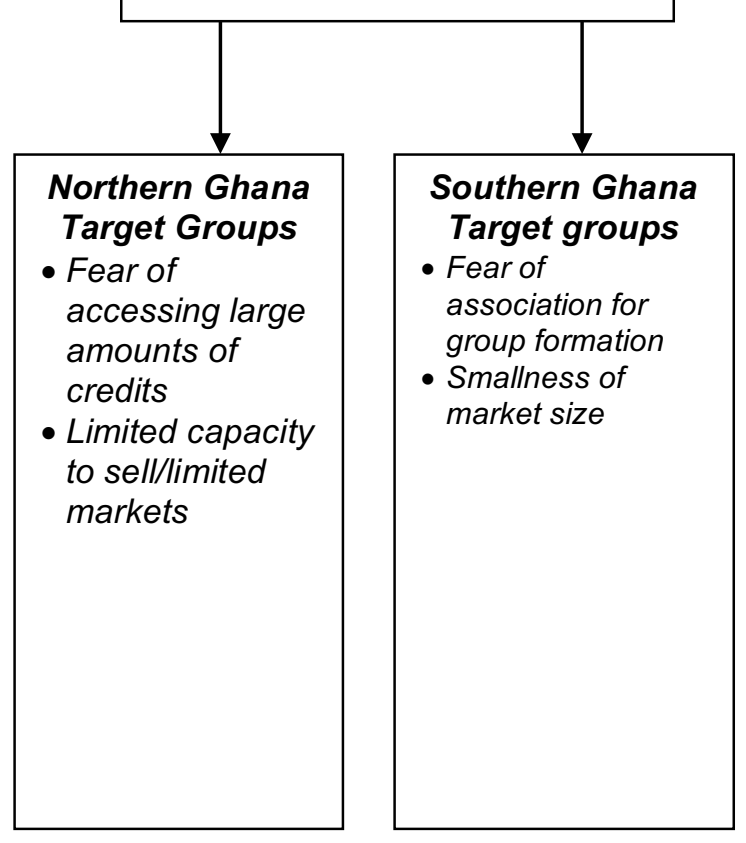

Source:" Author's construct,2016 
Table 1: Coping Strategies of Empowered Families/Target Groups

\begin{tabular}{|c|c|}
\hline Coping Means of Rural Target Groups & $\begin{array}{l}\text { Coping Means of Urban Target } \\
\text { Groups }\end{array}$ \\
\hline $\begin{array}{l}\text { 1. Re-engaging in the activities } \\
\text { they were involved in before the } \\
\text { intervention } \\
\text { 2. Showing unconcern attitude } \\
\text { towards children re-engaging in } \\
\text { WFCL } \\
\text { 3. Continuous use of children in } \\
\text { WFCL } \\
\text { 4. Condoning intermittent school } \\
\text { attendance by children } \\
\text { 5. Use of small family loans to } \\
\text { engage in the new skills } \\
\text { 6. Sale of property (e.g. cloth) to } \\
\text { raise money to start activities in } \\
\text { the area trained } \\
\text { 7. Reliance on Implementing } \\
\text { Agencies for support } \\
\text { 8. Over-reliance on informal credit } \\
\text { provided by itinerant buyers }\end{array}$ & $\begin{array}{l}\text { 1. Re-engaging in either same form } \\
\text { of other forms of activities } \\
\text { similar to the situation before } \\
\text { the intervention } \\
\text { 2. Return of children to WFCL } \\
\text { 3. Putting of skills into action for } \\
\text { those that do not require capital } \\
\text { (especially masons, } \\
\text { 4. Limited number access credit } \\
\text { from some credit institutions } \\
\text { like Pro-Credit etc } \\
\text { 5. Infrequent attendance of school } \\
\text { by children } \\
\text { 6. Unable to utilise time leading to } \\
\text { engagement in social vices }\end{array}$ \\
\hline
\end{tabular}

Author's construct, 2015.

These coping strategies have serious implications for the broader goal of the ILO/IPEC family empowerment interventions. The huge resources invested in sensitisation, awareness creation, social mobilisation and skills training are not achieving the desired results. The possibilities are high that children will be withdrawn from one form of WFCL and be re-engaged in other similar and sometimes highly unacceptable WFCL. Target groups themselves also tend to perpetuate their conditions of poverty, vulnerability and exclusion. If the interventions are not able to provide positive image of them to be attractive to funding agencies, the obvious task is to adopt alternatives including supply-led funding schemes with its attendance consequences.

\section{Repositioning Target Groups to access funding services}

Consultations with key financial sector professionals and small scale entrepreneurs revealed a two-way approach in dealing with the hypothesis of funding services against the special needs of poor empowered families. The financial sector practitioners contend that the following issues will reposition the target groups to attract the attention and confidence of funding agencies.

\section{Skills development}

Almost all the skills acquired by poor empowered families came from informal training at the micro-level without certification. Thus, target groups are unable to provide proof of training to win the confidence of funding agencies to help groups secure credit and loans. This is partly due to the fact that the formal training institutions charge too high for sponsors to be able to reach a significant number of beneficiaries. The obvious choice is for sponsors to rely on private small scale trainers who lack accreditation. Worse of all is that trainees are also not giving certificates duly signed by representatives of credible institutions. Ideally certificates from the NBSSI, NVTI, ITTUs, GRATIS, MDPI and from the various recognised Business Associations will suffice.

In the specific context of target groups, funding agencies demand that the skills being provided should be viable to produce marketable products which will enable client to repay loans on 
time and in full. The specific technical processes to facilitate attractions to funding agencies include the following:

\section{Group Formation/Development}

The risk associated with dealing with individuals in funding services is enormous compared to dealing with a group or cooperative. Boapeah $(1994)^{1}$ asserts that the important role cooperation plays in the development process includes the development of the spirit of independence, self-help and neighbourly assistance and the establishment of input supply system. This falls in line with the proposals of financial sector practitioners who believe that the institutional support systems currently recognise groups, cooperatives, societies and associations.

The formation of groups should involve technical support in group dynamics. This implies that groups should have executive members, be backed by some legal entity (e.g. registration with the District Assembly), and have regular meeting schedules. In terms of membership, the Ghana Cooperative department requirement is for membership of not less than 12 members in a group. However, funding agencies do not operate in the strict sense of this requirement. Funding agencies indicated members of between 5 and 25 in a group is desirable.

\section{Infrastructure Development and Technology}

The basic problem of lack of identification (including poor house numbering) translates into the risk of lending from funding agencies. If one cannot be traced to a home, at least showcasing a worksite with infrastructure depicting the enterprise will appeal to the borrower to consider the application for credit. Likewise, use of appropriate technology will underscore the marginal propensity to repay the credit.

\section{Viability of Investment Opportunity}

Funding of economic activities are done with three key motives. First, in the case of financial institutions including MFIs, the basic motive is profit making. Second, in the case of the FNGOs, the mixed motive of social responsibility and "break-even" returns for running of the organisation comes into play. Third, for Project Funding and direct GoG support funding sources, national interest of poverty reduction and social responsibility are the key motives. These three motives are diverse in nature. One thing is important irrespective of the specific motive and that is the need to create a process of a "System for Revolving Funding" in which case the available fund could cover a larger segment of the intended beneficiaries from time to time. The implications are that investments to be funded by funding agencies must prove to be viable of yielding considerable returns to enable the borrower to pay back the loan in full and in good time so that others could also access the fund.

On the above premise, funding agencies indicated that it is not just enough for target families to be given skills training in various economic activities. The kind and nature of the skills provided is crucial. Such training requires an integrated approach based on the specific economic characteristics of the district and the immediate catchment area of the community, raw material supply and market outlets.

${ }^{1}$ Boapeah, Samuel N. (1994) - Developing Small Scale Industries in Rural Regions: Business Behaviour and Appropriate Promotion Strategies with reference to Ahanta West District of Ghana, SPRING Centre, Dortmund 


\section{Payment of Initial "Commitment Fee"}

All funding agencies require the payment of initial sum as commitment fee and the amount differ from agencies to the other. The payment of the "Commitment Fee" is necessary for several reasons and also differs by each agency. For some it represents the individuals or groups commitment to mutual agreement for funding. To others is for either processing of funding, registration of the individual's/group's document or as a retention fee in case of default.

An assessment of the payment of the "Commitment Fee" reveals two positions. In one vein, the funding agencies assertion has some merits as it cushions the level of risk associated with dealing with the client. The justification is that once an individual is willing and able to raise the "Commitment Fee" is a demonstration of a good measure of seriousness to participate in the mutual agreement. The fact is that the burden to raise the fee will obviously push not only less serious partners away, but will also weed out the ones that represent high risk of funding. In other breath, the raising of the "Commitment Fee" poses insurmountable constraints for targets groups' capacity to participate in such mutual agreement. Already they are poor, vulnerable and excluded and so any such requirement pushes majority out of the funding arrangement.

\section{Provision of Guarantors}

Funding agencies indicated the requirement for loans borrowed to be guaranteed. Guarantors generally provide surety to the funding agencies to assure a high propensity to recover loans lend to clients. An analysis of the mode for guaranteeing of loans differs from one agency to the other.

\section{Payment of Interest Rates}

By far, payment of Interest Rates constitutes one of the serious handicaps in the process of funding to target groups

\section{Provision of Guarantors}

Funding agencies indicated the requirement for loans borrowed to be guaranteed. Guarantors generally provide surety to the funding agencies to assure a high propensity to recover loans lend to clients. An analysis of the mode for guaranteeing of loans differs from one agency to the other.

\section{Initial Deposit and Opening of Bank Account}

There is generally not a strict requirement for potential borrowers to open bank account even though some funding agencies require that. However, since loans are usually are in the form of bank-to-bank transactions, the normal thing is for the borrower to open a bank account (i.e. savings account) through which the loan granted will be channelled. Hitherto, raising the initial deposit coupled with the problem of going through the processes of opening the bank account was in itself frustrating especially to rural target groups. In the current dispensation, the processes of opening bank account have been streamlined to the extent that some banks permit opening of "cashless account" making it flexible for individuals and groups to operate a bank account.

\section{SUMMARY OF FINDINGS AND RECOMMENDATIONS: AND THEIR IMPLICATIONS FOR TARGET GROUPS ACCESS TO FUNDING SERVICES \\ Summary of major Findings}

The analysis of consultations, interviews and discussions have provided a unique opportunity for initiating dialogues with funding agencies to improve funding services target group. The 
study has explored the dynamics in the funding system within the perspective of the various funding sources (GoG support funding, project funding and MFIs funding) with useful lessons learned. Several people have received skills training in various disciplines but who cannot simply utilise the skills acquired to improve their livelihoods and consequently help their children to go and remain in school or apprenticeship/vocational training.

Whilst this study seeks to provide avenue for enhancing approaches for assisting target groups in accessing funding, findings and recommendations have been made in the course of the analysis throughout the study. However, the following major findings are outlined upon which basis succinct recommendations were made.

\section{Existence of financial and micro-credit schemes}

Throughout Ghana, financial institutions, micro-finance agencies and micro-credit schemes exist at both the national and sub-national levels. But a significant number are located in the urban areas and medium-size towns where they can reach their preferred target beneficiaries. Both in the cities, medium-size towns, small towns and rural communities, traditional moneylenders, susu groups also exist with a niche of the market.

\section{Inappropriate arrangement of funding services to benefit empowered families}

Based on the review of the operations of financial agencies in their lending policy and arrangements, the poor empowered families are not catered for. The conventional banks, nonbank financial institutions and number of micro-credit schemes have systematised lending arrangements which in their present arrangement still do not favour the target groups who are largely poor and vulnerable.

\section{High credit-risk among empowered families}

Provision of credit of all forms comes with some element of risk which may come in various dimensions. To reduce to barest minimum the associated credit risk, funding agencies package the services to include project appraisal, provision of securities, interest rates etc. The situation of the target groups is entirely more risky. They lack securities, start-up capital, bank accounts, and business plans/feasibility reports to convince funding agencies to meet their special needs. The implications are that poor empowered families have absolutely limited chances of benefiting from structured systems.

\section{Limited Focus on non-Financial services}

The provision of funding services has been characterised by overemphasis on financial products (loans and savings) without a corresponding attention paid to related non-financial products (transparency, accountability etc). The present situation does not allow efficient delivery that achieves the overriding purpose.

\section{Limited Institutional Representation}

Sustainability of MF services is key if target groups are to be assisted to move themselves from poverty. The most appropriate MF delivery mechanism should depend on local context to ensure capacity and cost effectiveness. It is therefore important that local institutions, particularly NGOs participate in the MF delivery processes at the local level. The study noted that the presence and participation of these institutions as intermediaries for MFIs and other funding agencies is weak. The solution has been to resort to direct delivery by these funding agencies. 


\section{Undeveloped systems for collaboration}

The effectiveness of MF, given the circumstances of target groups, will be based on development of strong collaboration and partnerships. Such collaboration and partnerships will enhance a collective approach at meeting the needs of target groups. So far, there is no such collaboration and partnerships still remain week.

\section{Key Recommendations}

The study has already proposed recommendations throughout the discussions and it is expected that these would be considered and implemented to facilitate the process of reaching out to target groups. Given the broad issues raised in the discussions, the following succinct recommendations are provided towards development of a comprehensive system that will target the specific needs of the target groups.

\section{Development of innovative products specific to the needs of target groups}

The study has identified quite explicitly the characteristics of the target groups. It is very obvious that they remain a group which needs to be consciously assisted to participate in their own development. The funding agencies should develop innovative pro-poor MF methodologies that attract the poorest of the poor, capable of reaching down to the target groups. Funding agencies should be extending services to poorest regions, districts and communities where MF activities do not normally operate. It must however be noted that this will not be achieved without a kind of "affirmative action" to conscious engage funding agencies to go extra mile in developing such products. It is therefore important that ILO working through the Ministry of Manpower and Labour Relations, Ministry of Gender and Social Protection, Ministry of Local Government and Rural Development and other collaborators will engage funding agencies to negotiate on the feasibility of reaching out to the target groups.

\section{Streamlining skills training for target groups}

Provision of skills is a complex activity driven by the capacity of both the provider and the beneficiary; approach and delivery mechanism which also require professionalism and focus. The skills empowerment programme was left to the discretion of the IAs without guidelines and operational manuals as to the content and scope of training. The tendency is for each provider to use the easy option in delivery the skills. This does not augur well for situations that require pragmatic solutions. The IAs should be able to re-assess the nature and depth of the skills provided, and where necessary re-align the trends in order to meet the requirement of funding agencies.

It is also necessary that a focus approached is used. The ILO being the key player in this regard should develop guidelines and operational manuals to govern provision of skills to beneficiaries. This could be done after the negotiations with funding agencies are completed at which stage it is expected that funding agencies would have outlined their requirements in clearer terms.

\section{Scaling up Institutions Representation of MF at local level}

The issue of capacity to reach out to target is related strongly to the choice of delivery mechanisms. The engagement of local level institutions is important as much as the involvement of district level actors. The consultations and negotiations with institutions for adequate representation should extend to cover local Community Based Organisations to enable them provide complementary services for MF provisions. 


\section{Increase the ranking of ILO and collaborators involvement in MF services}

The emerging issues for MF provision to target groups require interventions deeply rooted in the upstream negotiations. The Apex bodies of funding agencies wield enormous power and framework to represent the views and aspirations of their members. The engagement of apex bodies should be the responsibility of ILO. Recognising also that ILO is not a national body corporate, it is necessary for ILO to liaise with the MMYE to mediate for IAs through acknowledgment and certification so that IAs could access direct GoG support packages like MASLOC for its target groups.

\section{CONCLUSION}

There is a growing concern among government, private sector, civil society and development partners about the plight of the segment of the population with characteristic of the target groups. Poverty is the key factor that plagues the development of these populations. They are subsequently compelled by their circumstances to engage in activities that reduces their dignity, encourage their children to be engaged in child labour and in the process mortgage their future development as responsible citizens of society. The implications of this phenomenon are well known, attracting all manner of interventions with the view of empowering this category of people to assert themselves and move from poverty.

The GoG/ILO having provided for skills and management training, this research is to link target groups to funding services from funding agencies. The study examined in broad detail the technical assistance that would facilitate the linkage process.

Extensive consultations with financial institutions and other micro-credit service providers have culminated in a design of decision criteria to enhance the chances of empowered families' access to funding services. Several recommended actions have been proposed in this exercise and it is believed that once efforts are made to implement them, the stage will be set for target groups to access funding. It is also important to note again that the direct involvement of ILO, working through the Sector Ministry, Ministry of Manpower and Employment, will be needed to engage apex bodies of funding agencies in negotiations to increase the chances of a wider consultation towards development of more pro-poor interventions and products.

\section{References}

Abunyuwah, I. and Blay, J.K. (2013). Accessibility Constraints of Small-Scale Fish Farmers to Formal Credit in the Nzema East Municipality. Journal of Economics and Sustainable Development. Vol.4 (1). IISTE

Anku, M. (2011) child labor a Fight for All .GNA (www.modernghana.com/news)

Bank of Ghana. (2014). "Bank of Ghana: Licensed Banks, Representative Offices and their Registered Offices in Ghana as at December 2013". Retrieved 4 September 2014.

Bank of Ghana (2015). "Register of Non-Bank Financial Institutions as of December 2013". www.bog.gov.gh. Retrieved 28 February 2015.

Food and Agriculture Organisation (2014). Building a Common Vision for Sustainable Food and Agriculture: Principles and Approaches. Rome. ISBN 978-92-5-108471.

Ghana Statistical Service. (2014). Ghana Living Standard Survey (round 6) Assembly Press. Ghana.

Human Right watch. (2015). World Report, ISBN 13-978-1-4473-25482-2. United States.

International Labour Organisation (2004). West Africa Cocoa/ Commercial Agriculture Programme to Conbat Hazardous and Exploitative Child Labour.

ILO (2006).SIMPOC Strategic Note.

International demographic workers federation, http://www.idwfed.org/en 
International Programme for the Elimination of Child Labour (2014) Elimination hazardous child labor and occupational safety, health and Environmental Risk; A manual for agents of change in cocoa communities in Ghana ILO. ISBN 978-92-2-128953-1

IPEC- (2005). Combating Child Labour in Cocoa Growing websitewww.ilo.org/public//english/standards/ipec/themes/cocoa/

Lane, J. (2014). The Myth of Sustainability. Journal of Management and Sustainability. ISSN 1925-4725 (Print) ISSN 1925-4733 online.

National Development Planning Commission (NDPC) (2014). Monitoring and Evaluation Report.Accra.Ghana

National Development Planning Commission (NDPC) (2014). Annual Progress Report. Assembly Press.

Accra.Ghana

Republic of Uganda (2012). National Action Plan on the Elimination of the Worst Form of Child Labour in Uganda.. Kampala. (http://www.mglsd.go.ug.

Sacket, M.(2007) Forced Child Labour and Cocoa Production in West Africa.www.du.edu./hrhw research digest.

Sutton, P. (2002) Towards environmental sustainability.

United Nations Environmental Programme (2016). UNED Frontiers 2016 Report: Emerging Issues of Environmental Concern.

United Nations (2002). Report of the world Summit on sustainable development. New York

World Wildlife Fund (2015).Building a Sustainable Future. WWF. 